\title{
Pengaruh ROA, CR, dan DER terhadap harga saham perusahaan manufaktur subsektor food and beverage yang terdaftar di BEI Tahun 2015-2019
}

\section{Zulham Azari Lubis; Thomas Firdaus Hutahaean*; Silvia Kesuma; Anju Veronika Karin}

\author{
Jurusan Manajemen Keuangan, Fakultas Ekonomi, Universitas Prima Indonesia \\ *E-mail korespondensi: firdausthom@yahoo.com
}

\begin{abstract}
This study was made to know the effect of return on assets, current ratio, and debt to equity ratio on stock prices of manufacturing companies in the food and beverage subsector listed on the Indonesia Stock Exchange in the 2015-2019 period. This study uses a quantitative approach with a descriptive statistical analysis type. The data used is sourced from financial data on the Indonesia Stock Exchange and has been selected based on predetermined criteria. The population in this study amounted to 31 companies, using a purposive sample. The samples obtained were ten companies in the last five years. The results of this study indicate that partially the current ratio and debt to equity ratio do not have a positive and significant effect on stock prices. Partly, the return on assets has a positive and significant impact on stock prices. Return on assets, current ratio, and debt to equity ratio as independent variables simultaneously have a substantial effect on the variable stock price of manufacturing companies.
\end{abstract}

Keywords: Return on assets, Current ratio, Debt to equity ratio, Stock price

\begin{abstract}
Abstrak
Penelitian ini dibuat dengan tujuan untuk mengetahui pengaruh return on asset, current ratio, dan debt to equity ratio terhadap harga saham perusahaan manufaktur subsektor food and beverage yang terdaftar di Bursa Efek Indonesia pada periode 2015-2019. Penelitian ini menggunakan pendekatan kuantitatif dengan tipe penelitian deskriptif analisis statistik. Data yang dipakai bersumber dari data keuangan di Bursa Efek Indonesia dan sudah diseleksi berdasarkan kriteria yang telah ditentukan. Populasi pada penelitian ini berjumlah 31 perusahaan, dengan menggunakan purposive sample maka sampel yang didapatkan sebanyak 10 perusahaan dalam 5 tahun terakhir. Hasil penelitian ini menunjukkan bahwa secara parsial current ratio dan debt to equity ratio tidak memiliki pengaruhi positif dan signifikan terhadap harga saham. Secara parsial return on asset memiliki pengaruhiyang positif dan signifikan terhadap harga saham. Return on asset, current ratio dan debt to equity ratio sebagai variabel independen secara simultan berpengaruh signifikan terhadap variabel harga saham perusahaan manufaktur.
\end{abstract}

Kata kunci: Return on asset, Current ratio, Debt to equity ratio, Harga saham

\section{PENDAHULUAN}

Revolusi Industri yang dimulai pada abad ke-18 dan terus mengalami perkembangan dan kemajuan sampai abad ke-20 ini telah menyebabkan banyak perusahaan yang memilih untuk bergerak di bidang manufaktur. Hal ini didasari bahwa pembuatan produk yang semakin efisien dan efektif dengan tidak lagi mengandalkan tenaga manual namun telah menggunakan mesin-mesin yang semakin canggih dan berteknologi tinggi. Akan tetapi, hal ini tetap membuat persaingan bisnis dalam bidang produksi menjadi cukup ketat. Hal ini yang akan membuat perusahaan agar selalu siap menghadapi segala 
rintangan yang akan terjadi. Persaingan usaha ditengah kondisi perekonomian Indonesia yang cenderung bergerak naik dan turun menuntut para pelaku usaha untuk semakin meningkatkan kinerja usahanya dengan ide kreatif dan inovatif serta mencari strategi bersaing demi memenangkan kelangsungan hidup perusahaannya. Ketika perusahaan mempunyai manajemen yang baik maka akan terciptanya iklim investasi yang akan mendorong para investor untuk menanamkan modalnya pada perusahaan untuk semakin maju. Setiap perusahaan mempunyai pandangan tujuan perusahaan yang berbeda. Pada Perkembangan dan pertumbuhan ini juga bisa meningkatkan tujuan perusahaannya itu dengan cara meningkatkan profitabilitas perusahaan yang salah satu caranya yaitu dengan semua pemegang saham memperoleh keuntungan dari setiap lembar saham investasi atas investasi yang akan ditanamkannya. Keuntungan yang diperoleh berasal darilaba bersih perusahaan maupun daripeningkatan harga saham dibursa efek.

Salah satu indikator yang mempengaruhi Harga Saham adalah Rasio Likuiditas, Rasio Profitabilitas dan Rasio Solvabilitas. Dalam penelitian ini, rasio yang digunakan adalah Return On Assets (ROA), Current Ratio dan Debt To Equity Ratio (DER).

Pada Tahun 2015-2016 PT Indofood Sukses Makmur Tbk mengalami kenaikan sebesar 1,58 kali pada Return On Assets. Namun, harga saham mengalami kenaikan sebesar 2.750 atau 53,14\%. PT Indofood CBP Sukses Makmur Tbk pada tahun 20162017, Current Ratio mengalami kenaikan sebesar 0,80 kali. Namun, harga saham mengalami kenaikan sebesar 325 atau 3,79\%. PT Akasha Wira International Tbk pada tahun 2018-2019, Debt To Equity Ratio mengalami kenaikan sebesar 0,54 kali. Namun, harga saham mengalami kenaikan sebesar 125 atau $13,59 \%$.

Berdasarkan Uraian di atas, maka peneliti tertarik untuk melakukan penelitian dengan judul: "Pengaruh ROA, CR, dan DER terhadap Harga Saham Perusahaan Manufaktur Subsektor Food and Beverage Yang Terdaftar di BEI Tahun 2015-2019”

\section{LANDASAN TEORI}

\section{Teori pengaruh return on assets terhadap harga saham}

Menurut Herry (2012 : 196), semakin tinggi Return On Assets maka semakin baik produktivitas asset dalam memperoleh keuntungan bersih. Hal ini selanjutnya akan meningkatkan daya tarik perusahaan kepada investor karena tingkat pengembalian juga akan semakin besar. Hal ini akan berdampak bahwa harga saham dari perusahaan tersebut di pasar modal juga akan semakin meningkat sehingga Return On Assets akan berpengaruh terhadap harga saham perusahaan.

$\mathrm{H} 1$ : Return on assets berpengaruh terhadap harga saham

\section{Teori pengaruh current ratio terhadap harga saham}

Dalam Jurnal Prayudita Maulita dan Mujino, Current Ratio (Rasio Lancar) menunjukkan kemampuan perusahaan untuk memenuhi kewajiban lancarnya yaitu biaya operasional. Current Ratio yang tinggi akan menimbulkan kepercayaan investor karena perusahaan dinilai memiliki kemampuan untuk memenuhi kewajiban jangka pendek termasuk dalam membagikan deviden, sehingga dapat meningkatkan permintaan saham perusahaan tersebut sehingga harga saham naik. Tetapi, current ratio yang terlalu rendah juga dapat menghambat operasi perusahaan mengakibatkan perusahaan tidak mampu memenuhi permintaan,sehingga menekan laba. Penelitian ini sesuai dengan hasil penelitian Egi Ferdianto (2014) yang menyatakan Current Ratio tidak berpengaruh signifikan terhadap harga saham.

$\mathrm{H} 2$ : Current ratio berpengaruh terhadap harga saham 


\section{Teori pengaruh debt to equity ratio terhadap harga saham}

Dalam Jurnal Amanda, A., Darminto, Husaini, A. (2013) menyatakan bahwa Debt To Equity Ratio (DER) berpengaruh secara signifikan terhadap harga saham. Sedangkan dalam Jurnal Abied Luthfi Safitri (2013) menyatakan bahwa Debt To Equity Ratio (DER) tidak berpengaruh terhadap harga saham. Rasio ini menunjukkan komposisi atau struktur modal dari total pinjaman atau hutang terhadap total modal yang dimiliki perusahaan, Debt To Equity Ratio (DER) menunjukkan sejauh mana perusahaan dapat menanggung kerugian tanpa harus membahayakan kepentingan krediturnya. Semakin kecil rasio ini, berarti semakin besar pula jumlah aktiva yang didanai oleh pemilik perusahaan dan semakin besar penyangga resiko kreditur.

H3 : Debt to equity ratio berpengaruh terhadap harga saham

\section{Teori harga saham}

Menurut Darmadji dan Fakhruddin (2012:5) menyatakan saham adalah tanda penyertaan atau kepemilikan seseorang atau badan dalam suatu perusahaan atau perseroan terbatas. Saham berwujud selembar kertas yang menerangkan bahwa pemilik kertas tersebut adalah pemilik perusahaan yang menerbitkan surat berharga tersebut.

Menurut Hartono (2013:157) menyatakan harga saham adalah harga suatu saham yang terjadi di pasar bursa pada saat tertentu yang ditentukan oleh pelaku pasar dan ditentukan oleh permintaan dan penawaran saham yang bersangkutan di pasar modal.

\section{METODE}

Tempat penelitian ini pada Bursa Efek Indonesia melalui situs resmi yang diakses secara online, yaitu www.idx.co.id. Data yang digunakan dalam penelitian ini adalah data sumber sekunder yakni data laporan keuangan Perusahan Manufaktur Subsektor Food and Beverage pada Tahun 2015-2019. Data penelitian ini didapatkan dari situs resmi Bursa Efek Indonesia yang diakses secara online yaitu www.idx.co.id._Jenis Penelitian yang digunakan dalam penelitian ini adalah deskriptif.

\section{Populasi dan sampel}

Populasi dalam penelitian ini adalah Perusahaan Manufaktur Subsektor Food and Beverage yang terdaftar dan mengumumkan laporan keuangannya di Bursa Efek Indonesia pada Tahun 2015-2019 dan yang bersumber dari www.idx.co.id dan www.idnfinancials.com. Berdasarkan populasi yang sudah ditentukan terdapat 31 perusahaan.

Tabel 1. Sampel peneletian

\begin{tabular}{clc}
\hline No & \multicolumn{1}{c}{ Sektor } & Jumlah \\
\hline 1 & $\begin{array}{l}\text { Perusahaan manufaktur subsektor food and beverage } \\
\text { yang terdaftar di BEI pada periode 2015-2019 }\end{array}$ & 31 \\
2 & $\begin{array}{l}\text { Perusahaan manufaktur subsektor food and beverage } \\
\text { yang tidak mempublikasikan laporan keuangannya } \\
\text { lengkap pada periode 2015-2019 }\end{array}$ & $(2)$ \\
3 & $\begin{array}{l}\text { Perusahaan manufaktur subsektor food and beverage } \\
\text { yang tidak menghasilkan laba pada periode 2015-2019 } \\
\text { Perusahaan manufaktur subsektor food and beverage } \\
\text { yang tidak memenuhi persyaratan kategori tahun (IPO) }\end{array}$ & $(6)$ \\
\hline & \multicolumn{1}{c}{ Total sampel yang diteliti ( 10 x 5 periode) }
\end{tabular}

Sumber: Data diolah, 2020 
Sampel dalam penelitian ini dilakukan dengan cara purposive sampling. Purposive sampling yaitu teknik pengumpulan sampel dengan kriteria-kriteria tertentu. Sampel penelitiannya adalah laporan keuangan Perusahaan Manufaktur Subsektor Food and Beverage yang terdaftar di Bursa Efek Indonesia pada Tahun 2015- 2019 dan memiliki laba positif, terdapat perusahaan yang memenuhi syarat sebagai sampel dalam penelitian ini.

\section{Definisi variabel operasional}

\section{Return on assets}

Menurut Kasmir (2012:201), Return On Assets (ROA) merupakan rasio yang menunjukkan hasil (return) atas jumlah aktiva yang digunakan dalam perusahaan. Rumus return on assets yaitu sebagai berikut:

Return on Asset $=\frac{\text { Earning After Tax }(\mathrm{EAT})}{\text { Total Asset }}$

\section{Current ratio}

Menurut Hermanto dan Agung (2012 : 170), Current Ratio (Rasio Lancar) merupakan hasil pembagian antara jumlah aktiva lancar dibagi hutang lancar yang artinya tingkat keamanan bagi kreditor jangka pendek. Rumus current ratio dinyatakan sebagai berikut:

Current Ratio $=\frac{\text { Current Assets }}{\text { Current Liabilities }}$

\section{Debt to equity ratio}

Menurut Husnan dan Pudjiastuti (2012:73), menyatakan bahwa rasio ini menunjukkan perbandingan antara hutang dengan modal sendiri. rumus Debt to Equity Ratio yaitu:

Debt to Equity Ratio $=\frac{\text { Total Kewajiban }}{\text { Modal Sendiri }}$

\section{Uji asumsi klasik}

\section{Uji normalitas}

Menurut Ghozali (2016), uji normalitas dilakukan bertujuan untuk menguji apakah dalam model regresi, variabel independent atau variabel dependent (variabel residual) memiliki distribusi normal atau tidak.Dalam menganalisis data apakah berdistribusi normal atau tidak terdapat dua cara yaitu analisis grafik dan uji statistik.

\section{Uji multikolinieritas}

Menurut Ghozali (2016 : 103), uji multikolinieritas bertujuan untuk menguji apakah pada model regresi ditemukan adanya korelasi antar variabel - variabel bebas.

\section{Uji autokorelasi}

Menurut Ghozali (2016: 107), uji autokorelasi ini bertujuan untuk menguji apakah dalam model regresi linear ada kolerasi antara kesalahan pengganggu pada periode $t$ dengan kesalahan pengganggu pada periode $t-1$ (sebelumnya).

\section{Uji heteroskedastisitas}

Menurut Ghozali (2016 : 134), uji heteroskedastisitas bertujuan untuk menguji apakah dalam model regresi terjadi ketidaksamaan variabel dari residual suatu pengamatan ke pengamatan yang lain. 


\section{Uji analisis regresi linear berganda}

Menurut Ghozali (2016) uji analisis regresi linear berganda bertujuan untuk menguji lebih dari satu variabel bebas (metrik) terhadap satu variabel terikat (metrik).

$\mathrm{Y}=\mathrm{a}+\mathrm{b} 1 \mathrm{X} 1+\mathrm{b} 2 \mathrm{X} 2+\mathrm{b3X} 3+\mathrm{e}$

Dimana Y merupakan variabel dependen yaitu Harga Saham, $a=$ Konstanta, $b=$ Koefisien regresi, $\mathrm{X}=$ variabel independen yaitu ROA,Current Ratio dan DER,e= Persentase Kesalahan $(0,05)$.Setelah persamaan diatas terbebas dari asumsi dasar maka akan dilakukan pengujian hipotesis.

\section{Uji koefisien determinasi $\left(\mathbf{R}^{\mathbf{2}}\right)$}

Menurut Ghozali (2016), uji koefisien determinasi bertujuan untuk mengukur seberapa jauh kemampuan model dalam menenangkan variabel-variabel dependent. Nilai koefisien determinasi adalah nol dan satu.

\section{Uji simultan(F)}

Menurut Ghozali (2016:96), Uji Fdilakukan untuk mengetahui apakah semua variabel independen atau bebas yang dimasukkan secara bersama -sama mempunyai pengaruh yang signifikan terhadap variabel dependen atau terikat secara simultan (bersama-sama).

\section{Uji parsial (t)}

Menurut Ghozali (2016:97), pengujian ini dilakukan untuk menunjukkan seberapa jauh variabel independen (bebas atau penjelas) mempunyai pengaruh yang signifikan secara individual terhadap variabel dependen (terikat) secara parsial.

\section{HASIL DAN PEMBAHASAN}

\section{Hasil pengujian asumsi}

Variabel LN_ROA memiliki sampel 50 dengan nilai minimum -5.04 dan nilai maksimum -0.64 sedangkan nilai rata-rata -2.4817 dengan standar deviasi 0.95009 . Variabel LN_CR memiliki sampel 50 dengan nilai minimum -0.54 dan nilai maksimum 2.16 sedangkan nilai rata-rata 0.6882 dengan standar deviasi 0.70639 .

Tabel 2. Descriptive Statistik

\begin{tabular}{|l|r|r|r|r|r|}
\hline & \multicolumn{7}{|c|}{ Descriptive Statistics } \\
\hline LN_ROA & Minimum & Maximum & \multicolumn{1}{c|}{ Mean } & Std. Deviation \\
LN_CR & 50 & -5.04 & -.64 & -2.4817 & .95009 \\
LN_DER & 50 & -.54 & 2.16 & .6882 & .70639 \\
LN_HS & 50 & -1.81 & .67 & -.4210 & .78213 \\
Valid N (listwise) & 50 & 4.14 & 9.68 & 7.6166 & 1.47719 \\
\hline
\end{tabular}

Sumber : Data diolah, 2020

Variabel LN_DER memiliki sampel 50 dengan nilai minimum -1.81 dan nilai maksimum 0.67 sedangkan nilai rata-rata -0.4210 dengan standar deviasi 0.78213 . Variabel LN_HS memiliki sampel 50 dengan nilai minimum 4.14 dan nilai maksimum 9.68 sedangkan nilai rata-rata 7.6166 dengan standar deviasi 1.47719 . 


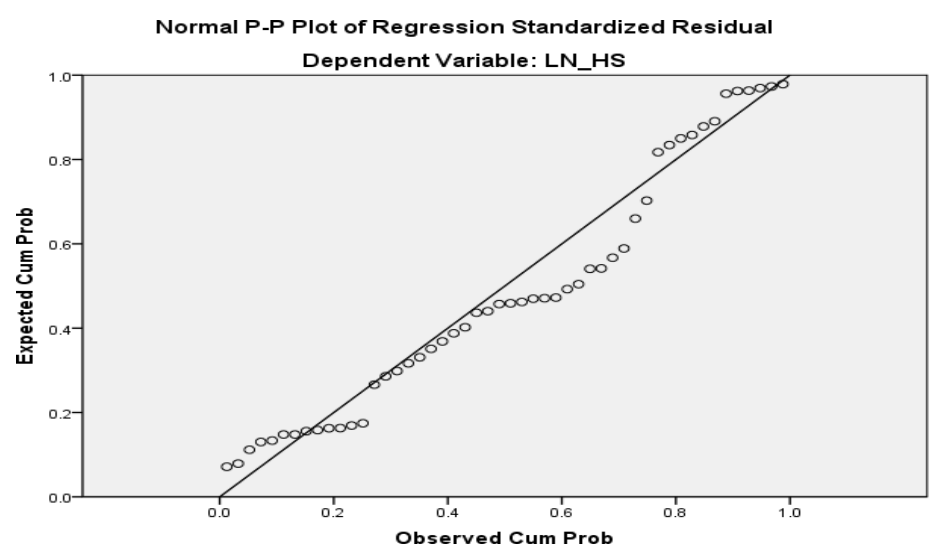

Sumber: data diolah, 2020

Gambar 1. Hasil uji grafik normalitas

\section{Uji normalitas}

Menurut Imam Ghozali (2011:160) model regresi dikatakan berdistribusi normal jika titik-titik atau data berada di dekat atau mengikuti garis diagonalnya. Pada gambar 3.1 grafik normalitas P-P Plot menunjukkan titik-titik yang tersebar mendekati garis diagonal, hal ini membuktikan data penelitian ini terdistribusi secara normal. Selain itu untuk mengetahui data terdistribusi normal pada penelitian ini menggunakan uji statistik non-parametik kolmogrov smirnov.

\begin{tabular}{|c|c|c|}
\hline \multicolumn{3}{|c|}{ One-Sample Kolmogorov-Smirnow Test } \\
\hline & & $\begin{array}{l}\text { Unstandardiz } \\
\text { ed Residual }\end{array}$ \\
\hline$N$ & & 50 \\
\hline \multirow[t]{2}{*}{ Normal Parameters ${ }^{a, b}$} & Mean & .0000000 \\
\hline & Std. Deviation & .89928409 \\
\hline \multirow[t]{3}{*}{ Most Extreme Differences } & Absolute & .137 \\
\hline & Positive & .137 \\
\hline & Negative & -.081 \\
\hline Kolmogorov-Smirnov Z & & .969 \\
\hline Asymp. Sig. (2-tailed) & & .304 \\
\hline
\end{tabular}

Sumber: data diolah,2020

Gambar 2. Hasil pengujian statistik normalitas

Berdasarkan hasil tes diatas nilai Kolmogorov Smirnov sebesar 0,969 dan Asymp. Sig.(2 - tailed) 0,304 dan nilai tersebut lebih besar dari 0,05 maka dapat disimpulkan bahwa nilai residual terdistribusi secara normal.

Uji Heteroskedastisitas

Tabel 4. Hasil uji heteroskedastisitas

Coefficients $^{a}$

\begin{tabular}{|c|c|c|c|c|c|c|}
\hline \multirow{2}{*}{\multicolumn{2}{|c|}{ Model }} & \multicolumn{2}{|c|}{ Unstandardized Coefficients } & \multirow{2}{*}{$\begin{array}{c}\text { Standardized } \\
\text { Coefficients }\end{array}$} & \multirow[b]{2}{*}{$\mathrm{t}$} & \multirow[b]{2}{*}{ Sig. } \\
\hline & & $B$ & Std. Error & & & \\
\hline \multirow[t]{4}{*}{1} & (Constant) & 546.613 & 441.040 & & 1.239 & .221 \\
\hline & LN_ROA & -93.537 & 154.296 & -.098 & -.606 & .547 \\
\hline & LN_CR & 285.715 & 527.715 & .221 & .541 & .591 \\
\hline & LN_DER & 21.205 & 495.038 & .018 & .043 & .966 \\
\hline
\end{tabular}

a. Dependent Variable: ABS_RES2

Sumber: data diolah, 2020 
Jika nilai signifikasi (sig) antara variabel independen dengan absolut residual lebih besar dari 0,05 maka tidak terjadi masalah heteroskedastisitas.Dari tabel diatas untuk variabel LN_ROA, LN_CR, dan LN_DER didapatkan nilai sig lebih besar dari 0,05 maka artinya semua variabel tidak mengalami masalah heteroskedastisitas.

\section{Uji multikolinieritas}

Menurut Imam Ghozali (2011:107) tidak terjadi gejala multikolinieritas jika nilai tolerance $>0,10$ dan nilai VIF $<10,00$. Dari hasil uji diatas nilai tolerance value semua variabel independen berada diatas 0,10 yaitu sebesar 0,807 untuk LN_ROA sebagai X1, 0,125 untuk LN_CR sebagai X2, dan 0,116 untuk LN_DER sebagai X3.

Tabel 5. Hasil uji multikolinieritas

Coefficients $^{a}$

\begin{tabular}{|c|c|c|c|c|c|c|c|c|}
\hline \multirow{2}{*}{\multicolumn{2}{|c|}{ Model }} & \multicolumn{2}{|c|}{ Unstandardized Coefficients } & \multirow{2}{*}{$\begin{array}{c}\text { Standardized } \\
\text { Coefficients } \\
\text { Beta }\end{array}$} & \multirow[b]{2}{*}{$t$} & \multirow[b]{2}{*}{ Sig. } & \multicolumn{2}{|c|}{ Collinearity Statistics } \\
\hline & & $\mathrm{B}$ & Std. Error & & & & Tolerance & VIF \\
\hline \multirow[t]{4}{*}{1} & (Constant) & 10.806 & .444 & & 24.330 & .000 & & \\
\hline & LN_ROA & 1.238 & .155 & .796 & 7.968 & .000 & .807 & 1.240 \\
\hline & LN_CR & -.268 & .531 & -.128 & -.504 & .617 & .125 & 8.015 \\
\hline & LN_DER & -.160 & .499 & -.085 & -.321 & .749 & .116 & 8.647 \\
\hline
\end{tabular}

a. Dependent Variable: LN_HS

Sumber: Data diolah, 2020

Sedangkan nilai VIF antara variabel X1, X2, dan X3 berada dibawah 10. Maka dapat disimpulkan bahwa penelitian ini berdasarkan nilai tolerance dan vif tidak terjadi multikolinieritas.

\section{Uji autokorelasi}

Menurut Imam Ghozali (2011 : 11) Tidak ada gejala autokorelasi, jika nilai Durbin Watson terletak antara dU sampai dengan (4-dU). Berdasarkan tabel diatas, diketahui nilai Durbin Watson sebesar 1.193.

Tabel 6. Hasil uji autokorelasi

\section{Model Summary}

\begin{tabular}{|l|l|r|r|r|r|}
\hline Model & $\mathrm{R}$ & $\mathrm{R}$ Square & $\begin{array}{c}\text { Adjusted R } \\
\text { Square }\end{array}$ & $\begin{array}{c}\text { Std. Error of } \\
\text { the Estimate }\end{array}$ & $\begin{array}{c}\text { Durbin- } \\
\text { Watson }\end{array}$ \\
\hline 1 & $.793^{\mathrm{a}}$ & .629 & .605 & .92815 & 1.193 \\
\hline
\end{tabular}

a. Predictors: (Constant), LN_DER, LN_ROA, LN_CR

b. Dependent Variable: LN_HS

Sumber: Data diolah, 2020

Nilai ini terletak antara nilai dL 1.4206 dan dU 1.6739 sehingga tidak ada kesimpulan yang pasti tentang ada atau tidaknya gejala autokorelasi. Jika seperti ini yang terjadi, maka langkah yang harus dilakukan untuk mendeteksi autokorelasi adalah dengan uji run test.

Salah satu cara untuk mengetahui ada tidaknya autokorelasi pada model regresi adalah dengan melakukan uji Run Test (Ghozali,2016).Dasar pengambilan keputusan uji Run Test adalah: 1).Jika nilai Asymp. Sig.(2-tailed) lebih kecil < dari 0.05 maka terdapat gejala autokorelasi. 2).Jika nilai Asymp. Sig.(2-tailed) lebih besar > dari 0.05 maka tidak terdapat gejala autokorelasi. 
Tabel 7. Hasil uji run test

\begin{tabular}{|l|r|}
\multicolumn{2}{|c|}{ Rums Test } \\
\hline \multicolumn{1}{|c|}{} & $\begin{array}{c}\text { Unstandardiz } \\
\text { edResidual }\end{array}$ \\
\hline Test Value ${ }^{3}$ & -165.01481 \\
Cases \& Test Value & 25 \\
Cases = Test Value & 25 \\
Total Cases & 50 \\
Number of Runs & 22 \\
$Z$ & -1.143 \\
Asymp. Sig. (2-tailed) & .253 \\
\hline
\end{tabular}

Sumber: Data diolah,2020

Diketahui nilai Asymp. Sig.(2-tailed) sebesar 0,253 > dari 0.05, maka dapat disimpulkan bahwa tidak terdapat gejala autokorelasi, sehingga analisis regresi linier dapat dilanjutkan.

Tabel 8. Hasil uji t (parsial)

\begin{tabular}{|c|c|c|c|c|c|c|c|c|}
\hline \multicolumn{9}{|c|}{ Coefficients $^{\Xi}$} \\
\hline \multirow{2}{*}{\multicolumn{2}{|c|}{ Model }} & \multicolumn{2}{|c|}{ Unstandardized Coefficients } & \multirow{2}{*}{$\begin{array}{c}\text { Standardized } \\
\text { Coefficients } \\
\text { Beta }\end{array}$} & \multirow[b]{2}{*}{$t$} & \multirow[b]{2}{*}{ Sig. } & \multicolumn{2}{|c|}{ Collinearity Statistics } \\
\hline & & $\mathrm{B}$ & Std. Error & & & & Tolerance & VIF \\
\hline \multirow[t]{4}{*}{1} & (Constant) & 10.806 & .444 & & 24.330 & .000 & & \\
\hline & LN_ROA & 1.238 & .155 & .796 & 7.968 & .000 & .807 & 1.240 \\
\hline & LN_CR & -.268 & .531 & -.128 & -.504 & .617 & .125 & 8.015 \\
\hline & LN_DER & -.160 & .499 & -.085 & -.321 & .749 & .116 & 8.647 \\
\hline
\end{tabular}

a. Dependent Variable: LN_HS

Sumber: Data diolah, 2020

Berdasarkan hasil penelitian, maka diperoleh persamaan regresi sebagai berikut:

$\mathbf{Y}=\mathbf{a}+\mathbf{b}_{1} \mathbf{X}_{1}+\mathbf{b}_{2} \mathbf{X}_{2}+\mathbf{b}_{3} \mathbf{X}_{3}+\mathbf{e}$

$Y=10.806+1.238 X_{1}+(-0.268) X_{2}+(-0.160) X_{3}+e$

\section{Uji t (parsial)}

Secara parsial uji t untuk ROA terhadap Harga Saham adalah nilai t hitung sebesar 7,968 sedangkan t tabel sebesar 2,01290. Maka 7,968>2,01290 dengan nilai signifikan $0,000<0,05$. Hal ini berarti bahwa ROA memiliki pengaruh positif dan signifikan terhadap Harga Saham.

Secara parsial uji t untuk Cr terhadap Harga Saham adalah nilai thitung sebesar $-0,504$ sedangkan $t$ tabel sebesar 2,01290. Maka $-0,504<2,01290$ dengan nilai signifikan 0,617>0,05. Hal ini berarti bahwa $\mathrm{Cr}$ memiliki pengaruh negatif dan tidak signifikan terhadap Harga Saham.

Secara parsial uji $\mathrm{t}$ untuk DER terhadap Harga Saham adalah nilai $\mathrm{t}$ hitung sebesar -0,321 sedangkan $t$ tabel sebesar 2,01290. Maka $-0,321<2,01290$ dengan nilai signifikan 0,749>0,05. Hal ini berarti bahwa DER memiliki pengaruh negatif dan tidak signifikan terhadap Harga Saham.

\section{Uji koefisien determinasi}

Berdasarkan Tabel 9 menunjukkan nilai adjusted $R$ square adalah sebesar 0,605 atau 60,5\%. Hal ini berarti bahwa sebesar $60,5 \%$ variasi variabel Harga Saham dapat dijelaskan oleh variasi dari ketiga variabel independen (ROA, CR, dan DER). 
Sedangkan 39,5\% (100\%-60,5\%) sisanya dijelaskan oleh sebab-sebab lain diluar model penelitian. Koefisien determinasi penelitian ini dapat dikatakan memiliki pengaruh yang cukup tinggi atau kuat.

Tabel 9. Hasil pengujian koefisien determinasi $\mathrm{R}^{2}$

Model Summary

\begin{tabular}{|l|l|l|r|r|r|}
\hline Model & $\mathrm{R}$ & $\mathrm{R}$ Square & $\begin{array}{c}\text { Adjusted R } \\
\text { Square }\end{array}$ & $\begin{array}{c}\text { Std. Error of } \\
\text { the Estimate }\end{array}$ & $\begin{array}{c}\text { Durbin- } \\
\text { Watson }\end{array}$ \\
\hline 1 & $.793^{\mathrm{a}}$ & .629 & .605 & .92815 & 1.193 \\
\hline
\end{tabular}

a. Predictors: (Constant), LN_DER, LN_ROA, LN_CR

b. Dependent Variable: LN_HS

Sumber: Data diolah,2020

\section{Pengaruh ROA terhadap harga saham}

Hasil pengujian pertama pengaruh variabel ROA terhadap Harga Saham menunjukkan secara parsial nilai $\mathrm{t}$ hitung sebesar 7,968 sedangkan $\mathrm{t}$ tabel sebesar 2,01290. Maka 7,968 > 2,01290 dengan nilai signifikan 0,000<0,05. Hal ini berarti bahwa ROA memiliki pengaruh positif dan signifikan terhadap Harga Saham. Hasil penelitian ini konsisten dengan penelitian sebelumnya yang dilakukan oleh Pandansari (2012) yang menyatakan adanya pengaruh yang signifikan antara ROA dengan Harga Saham.

\section{Pengaruh CR terhadap harga saham}

Hasil pengujian kedua pengaruh variabel $\mathrm{Cr}$ terhadap Harga Saham menunjukkan secara parsial nilai t hitung sebesar -0,504 sedangkan t tabel sebesar 2,01290. Maka -0,504 <2,01290 dengan nilai signifikan 0,617>0,05. Hal ini berarti bahwa $\mathrm{Cr}$ memiliki pengaruh negatif dan signifikan terhadap Harga Saham.Hasil penelitian menunjukkan konsisten dengan penelitian sebelumnya yang dilakukan oleh Egi Ferdianto (2014) yang menyatakan Current Ratio tidak berpengaruh signifikan terhadap harga saham.

\section{Pengaruh DER terhadap harga saham}

Hasil pengujian ketiga pengaruh variabel DER terhadap Harga Saham menunjukkan secara parsial nilai $\mathrm{t}$ hitung sebesar $-0,321$ sedangkan $\mathrm{t}$ tabel sebesar 2,01290. Maka $-0,321<2,01290$ dengan nilai signifikan $0,749>0,05$. Hal ini berarti bahwa DER tidak memiliki pengaruh negatif dan signifikan terhadap Harga Saham. Penelitian ini konsisten dengan penelitian yang dilakukan oleh Indah Sulistya Dwi Lestari, Ni Putu Suryantini (2019) yang menyatakan DER tidak berpengaruh signifikan dengan arah negatif terhadap harga saham.

Pengaruh ROA, CR dan DER Terhadap Harga Saham

Berdasarkan hasil penelitian diketahui nilai signifikan untuk pengaruh X1, X2, dan X3 secara simultan terhadap $\mathrm{Y}$ adalah sebesar $0,000<0,005$ dan nilai $\mathrm{F}$ hitung $=26,040>$ daripada $\mathrm{F}$ tabel $=2,80$ sehingga bisa disimpulkan bahwa variabel independen berpengaruh secara simultan terhadap variabel dependen (harga saham).

\section{KESIMPULAN DAN SARAN}

\section{Kesimpulan}

Penelitian ini dilakukan untuk menganalisa pengaruh ROA, Current Ratio dan DER terhadap Harga Saham. Berdasarkan hasil analisa dan pembahasan yang telah dilakukan dan diuji menggunakan analisis regresi berganda, diperoleh kesimpulan bahwa ROA 
berpengaruh positif dan signifikan terhadap Harga Saham sedangkan Current Ratio dan DER berpengaruh negatif dan tidak signifikan terhadap Harga saham. Secara simultan $\mathrm{X} 1, \mathrm{X} 2$, dan X3 berpengaruh simultan terhadap Y.

\section{Saran}

Berdasarkan hasil kesimpulan atas penelitian mengenai pengaruh ROA, Current Ratio dan DER terhadap Harga Saham, maka saran yang bisa diajukan peneliti diantaranya: Bagi peneliti selanjutnya, alangkah baiknya memperhatikan bahwa secara parsial, hanya varibel Return on Asset yang berpengaruh signifikan terhadap Harga Saham perusahaan Food and Beverage di BEI periode 2015-2019,peneliti selanjutnya juga disarankan untuk mempertimbangkan faktor-faktor lain yang dapat mempengaruhi Harga Saham perusahaan selain menggunakan rasio Return on Asset,Current Ratio dan Debt to Equity Ratio.

Bagi investor, diharapkan penelitian ini dapat dijadikan dasar dalam proses pengambilan keputusan berinvestasi yang bijak dan tepat. Bagi Universitas Prima Indonesia, diharapkan bahwa penelitian ini dapat membantu memberikan kontribusi terhadap perkembangan pengetahuan untuk seluruh mahasiswa fakultas ekonomi.

\section{DAFTAR PUSTAKA}

Anwar, Saiful (2017). Analisis pengaruh debt to equity ratio (DER), return on asset (ROA), current ratio (CR), total assets turnover (TATO), dan price earnings ratio (PER) terhadap earning per share (EPS). Simki-Economic. Skripsi Universitas Nusantara PGRI: Kediri.

Ariskha Nordiana, dan Budiyanto (2017). Pengaruh DER, ROA, ROE dan EPS terhadap harga saham pada perusahaan food and beverage. Jurnal Ilmu dan Riset Manajemen. 6(2), 1-16

Astrid Amanda, Darminto, dan Achmad Husaini (2015). Pengaruh debt to equity ratio, return on equity, earning per share dan price earning ratio terhadap harga saham pada perusahaan food and beverage di BEI Periode 2008-2011, 1-12

Dina, Putu Aristya Dewi., Suaryana (2013). Pengaruh EPS, DER, dan PBV Terhadap Harga Saham. E-Jurnal Akuntansi Universitas Udayana, 4(1), 215-229

Fitrianingsih, Dwi dan Yogi Budiansyah (2018), Pengaruh current rasio dan debt to equity ratio terhadap harga saham di perusahaan food and beverage yang terdaftar di bursa efek Indonesia periode 2013-2017.Jurnal Riset Akuntansi Terpadu, 12(1),144166.

Ghozalli, Imam. (2013). Aplikasi analisis multivariate dengan program SPSS. Edisi Ketujuh, Universitas Diponegoro: Semarang.

NN. (2021). Bursa Efek Indonesia diakses dalam www.idx.co.id, Tanggal 2 Januari 2021, Pukul 12.00 WIB

NN. (2021). Indonesia Stock Exchange diakses dalam www.idnfinancials.com, Tanggal 2 Januari 2021, Pukul 12.00 WIB

Ramadhani, Fendi Hudaya. (2016). Pengaruh DER, ROE, dan NPM terhadap harga saham perusahaan sektor pertambangan yang terdaftar di Bursa Efek IndonesiaPeriodei2011-2015. Skripsi. Universitas Negeri Yogyakarta: Yogyakarta

Toto Prihadi. (2013). Analisis laporan keuangan teori dan aplikasi. Jilid 1. PPM: Jakarta. 